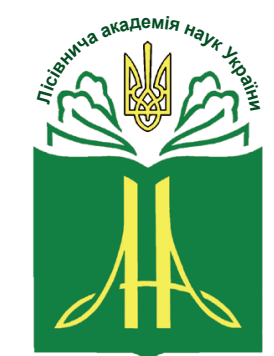

Forestry Academy of Sciences of Ukraine

Наукові праці Лісівничої академії наук України Proceedings of the Forestry Academy of Sciences of Ukraine

http://fasu.nltu.edu.ua https://doi.org/10.15421/411941

Article received 2019.06.15

Article accepted 2019.12.26
ISSN 1991-606X print

ISSN 2616-5015 online

(a) $\square$ Correspondence author

Lyudmyla Zahvoyska

lyudmyla.zahvoyska@nltu.edu.ua

General Chuprynka st., 103, Lviv, 79057, Ukraine

УДК 519.876.5:620.925 : [502.174.1:674.8:643]

\title{
Моделювання процесу енергетичного переходу методом системної динаміки: енергетичні кооперативи як інструмент переходу до сталого використання деревної біомаси в житловому секторі
}

\author{
Л.Д. Загвойська' ${ }^{1}$ О.В. Блецка²
}

Домінуюча парадигма енергогенерування цеентралізована, високовуглецева $і$ породжує енергетичну бідність. Імператив глобальної зміни клімату пріоритезує процес енергетичного переходу, одним із аспектів якого є стале енергетичне використання деревної біомаси. Обгрунтовано необхідність трансформацї енергетичного сектора шляхом використання холістичних методів дослідження $і$ деліберативних методів прийняття рішень. Побудовано причинно-наслідкову модель процесу енергетичного переходу і потокову модель поширення екоінновацій для процесу формування енергетичних кооперативів. За результатами регресійного аналізу макроекономічних показників глобальної конкурентоспроможності краӥн виконано параметризацію потокової моделі для умов України. За результатами моделювання, проведеного з використанням цієї моделі, встановлено, щзо проиес формування енергетичних кооперативів відбуватиметься повільно, насамперед - через неефективність інституиій. Однак, відповідно до здійсненого нами опитування в м. Борислав встановлено, щуо 18,1\% респондентів знайомі з концеепією енергетичних кооперативів, з яких кожен п'ятий готовий вкласти власні кошти в їхній розвиток, близько половини опитаних бажають змінити системи опалення в своїх помешканнях, щзо значно простіше зробити членам кооперативів. Використовуючи причинно-наслідкову модель, протестовано запропоновані нами SWOT-стратегї процесу покращення енергетичного використання деревної біомаси в житловому секторі, визначено додаткові важелі впливу, виявлено потенційні небажані наслідки $і$ джерела непевності, щзо сприятиме глибиому розумінню і кращуому управлінню процесом енергетичного переходу.

Ключові слова: трансформація енергетичних систем; кооперативна бізнес-модель; SWOT-аналіз $і$ стратегії; регресійний аналіз; причинно-наслідкова і потокова діаграми; деліберативні методи прийняття рішень.

Вступ. В умовах експоненційно наростаючої втрати якості довкілля (Steffen et al., 2011) та зміни клімату (Hansen et al., 2016) проблема забезпечення вищої ефективності, інклюзивності та екологічності енергетичного сектора - так званого процесу енергетичного переходу - набуває особливої ваги як у наукових дослідженнях, так і в політиці (Droege,
2011, Hansen \& Sato, 2016). Імператив глобальної зміни клімату змушує громадянське суспільство i бізнес, політиків і науковців до пошуку шляхів трансформування наявних енергетичних систем, які $\epsilon$ високоцентралізованими, вуглецемісткими і породжують енергетичну бідність (Bouzarovski \& Tirado Herrero, 2017).

\footnotetext{
Загвойська Людмила Дмитрівна - член-кореспондент Лісівничої академії наук України, кандидат економічних наук, доцент кафедри екологічної економіки. Національний лісотехнічний університет України, вул. Генерала Чупринки, 103, м. Львів, 79057, Україна. Тел.: +38-050-371-44-29. E-mail: lyudmyla.zahvoyska@nltu.edu.ua ORCID:https://orcid.org/0000-0002-0028-4723

2 Блецка Ольга Василівна - магістр з економіки довкілля і природних ресурсів. Національний лісотехнічний університет України, вул. Генерала Чупринки, 103, м. Львів, 79057, Україна. Тел.: +38-068-532-70-37; E-mail: olyakhust@gmail.com ORCID: https://orcid. org/0000-0002-0467-8068
} 
Підписання кліматичних угод у Кіото (1997), а згодом у Парижі (2015) дало поштовх цьому процесу, але водночас показало обмеженість впливу міжнародних і національних інституцій на нього. І хоч на рівні окремих регіонів і країн маємо достатньо переконливі приклади, такі як стратегія розвитку ЄС 2020, наднаціональні енергетичні ініціативи скандинавських країн (Grigoryeva et al., 2018), національні енергетичні ініціативи Бразилії та Франції (Solomon \& Krishna, 2011), місцеві енергетичні ініціативи в Німеччині i Нідерландах (Hoppe et al., 2015, Moss et al., 2015) та інші, все-таки необхідність інтенсифікації процесів переходу очевидна (Solomon \& Krishna, 2011).

Дослідження цих процесів базуються на різних теоретичних підходах. Зокрема, van der Kroonetal (2013) веде дослідження з позицій економіки домашніх господарств, вибудовуючи свої міркування щодо поведінки на ринку енергетичних послуг на неокласичній концепції раціонального споживача, який максимізує свою корисність, i, будучи добре поінформованим про всі технології та їхні впливи, вибудовує власну енергетичну драбинку, керуючись особистими вигодами. Зважаючи на обмеженість цього підходу (Simon, 1997, Zahvoyska \& Pelyukh, 2019, Bauwens et al., 2016) будують свої дослідження на концепції соціальних екологічних систем, запропонованій McGinnis \& Ostrom (2014), що дає змогу органічно поєднати діяльність індивіда в певному соціально-екологічному контексті, його суб' єктність, здатність до дії (agency) та інституціональний, біофізичний і технічний контекст перетворень (Stirling, 2014).

Світовий досвід підказує, що зміна головних енергетичних ресурсів відбувається десятиліттями, якщо уряд визнає і підтримує цей національний імператив (Solomon \& Krishna, 2011), тоді як причиною млявих і незлагоджених змін $є$ складність і багатоаспектність проблеми (Loorbach, 2010, Zahvoyska, 2005). Нексус енергетичного переходу охоплює питання ефективності власності, довкільні, технічні, соціальні, правові, організаційні та інші аспекти, регіональні та локальні контексти, а також питання ефективності взаємодії стейкхолдерів.

Ці особливості рельєфно виявляються у дослідженні енергетичного переходу в житловому сектоpi - широкомасштабному процесі соціальних, технічних і довкільних змін. Важливість досліджень цього процесу посилюється тим, що він дає змогу подолати проблему енергетичної бідності, тобто неможливості домашніх господарств забезпечити соціально та матеріально необхідний їм рівень енергетичних послуг (Bridge et al., 2013), а також забезпечити перехід до сталого використання відновних джерел енергії, зокрема деревної біомаси, що стримуватиме зміну клімату.

Тоді як процеси енергетичного переходу, їхні особливості, рушії і перешкоди досліджені на регіональному і національному рівнях для різних країн $\mathrm{CC}$ (Solomon \& Krishna, 2011, Moss et al., 2015, Hoppe et al., 2015, Ericsson \& Werner, 2016, Grigoryeva et al., 2018), в Україні такі дослідження поодинокі й обмежені рамками дисциплінарних підходів (Havrysh,
2008, Pastukh, 2016, Stoyko, 2018, Zahvoyska et al., 2007, Zinchenko, 2013).

Усі ці виклики: невідкладна необхідність переходу енергетичного сектора до відновних ресурсів, трансформування наявної енергетичної системи у децентралізовану і низьковуглецеву, ширше залучення місцевих громад до вирішення питань задоволення енергетичних потреб і подолання проблеми енергетичної бідності - актуалізують тему цього дослідження і роблять питання моделювання процесів енергетичного переходу важливими і невідкладними. Завданням цього дослідження є формування елементів організаційно-економічного забезпечення процесу енергетичного переходу в Україні.

Об'єкт і методика дослідження. Об 'єктом дослідження є процес енергетичного використання деревної біомаси населенням. Предмет дослідження - організаційно-економічне забезпечення енергетичного використання деревної біомаси в житловому секторі на засадах сталого розвитку. Мета дослідження полягає у розвитку організаційноекономічного забезпечення, розробленні імітаційних моделей для дослідження процесу і надання рекомендацій для забезпечення ефективного переходу до сталого енергетичного використання деревної біомаси у житловому секторі.

Хоча перші енергетичні кооперативи виникли ще на початку XX ст. у США, в європейських країнах кооперативи з відновлюваної енергетики почали поширюватися порівняно нещодавно. У 2011 р. було створено робочу групу з питань енергетики і довкілля в рамках Cooperatives Europe для розроблення загальної стратегії і заходів інтенсифікації процесу.

Енергетичний кооператив - це об'єднання громадян, яке створене для забезпечення їхніх енергетичних потреб (як індивідуальних, так і спільних), зокрема: задоволення власних потреб в електроенергії, теплі чи паливі; фінансування витрат на придбання енергогенеруючого обладнання або отримання аудиторських послуг для підвищення енергоефективності будівель; консультування з питань використання відновних джерел енергії тощо (Zinchenko, 2013). Спільна власність дає змогу членам кооперативу поділяти ризики неуспіху ініційованих кооперативом проектів усіма його членами, а також підвищувати ефективність його діяльності порівняно з ефективністю індивідуальної діяльності завдяки ефекту масштабу. У практиці Австралії, Данії, Німеччини, США та інших країн маємо переконливі приклади придбання енергетичними кооперативами вітрових турбін, сонячних панелей, обладнання для гідроелектростанцій та ін. на локальному і регіональному рівнях (Schreuer \& WeismeierSammer, 2010, Bauwens et al., 2016, Bouzarovski \& Tirado Herrero, 2017, Grigoryeva et al., 2018).

Енергетичні кооперативи є дієвим інструментом інтенсифікації процесу енергетичного переходу. Однак для його застосування необхідні відповідна законодавча підтримка, як це було, наприклад, в Австро-Угорщині, коли прийняття закону «Про 
кооперативні товариства» у 1873 р. дало поштовх до розвитку кооперативного руху в усій країні. Зокрема, на території Західної України особливо успішні кооперативні бізнес-моделі були в сільському господарстві, чому сприяла підтримка 3 боку греко-католицької церкви та особисто митрополита А. Шептицького (Prokop, 2010). Започаткування української кооперації потребувало відповідної економічної та агрономічної навченості, що стимулювало підвищення якості соціального капіталу. Згодом цей економічний успіх забезпечив підгрунтя українського національно-визвольного руху на цих теренах.

Процеси трансформації енергетичного сектора сьогодні відбуваються в синергії 3 процесами економічної та екологічної глобалізації і формування глобальних соціальних мереж, що помітно сприяє поширенню екоінноваційних практик у світі (Zahvoyska, 2014). Ця динаміка нелінійна i поширюється вона нерівномірно: існує сильна залежність від раніше прийнятих рішень, соціальноекономічного та інституціонального контекстів, глибини і системності охоплення різних сфер суспільної діяльності трансформаційними процесами (Loorbach 2010, Bouzarovski \& Tirado Herrero, 2017). Тому дослідження цих соціальних, технічних і довкільних змін потребує використання нових методів і підходів, які відображають синергетичний характер проблеми (Zahvoyska, 2013, Stirling, 2014). Охопити весь спектр питань, які породжує цей процес, достатньо складно, оскільки енергетичний сектор має тісні зв' язки з усіма сферами діяльності людини, а енергетична безпека є одним із пріоритетів сталого розвитку. Аналітичні інструменти і методи обгрунтування управлінських рішень мають бути чутливими до зміни цінностей, пріоритетів і критеріїв прийняття рішень.

Одним із таких інструментів є підхід системної динаміки (Meadows et al., 1972, Sterman, 2000). Системно-динамічні моделі зазвичай розглядають макроскопічний рівень економічних чи соціальних систем і використовують для цього лише одного агента 3 порівняно невисоким рівнем складності структури. У контексті парадигми системної динаміки досліджувану систему представляють на високому рівні абстракції - як взаємопов'язані процеси зі зворотними (підсилюючими чи балансуючими) зв'язками або як потоки, запаси і накопичувачі, які відображають взаємодію елементів системи.

Перевага методів системної динаміки, порівняно 3 іншими методами імітаційного моделювання, полягає в можливості дослідити траєкторії і час, необхідний для досягнення бажаного рівня розвитку, тобто процеси руйнування наявного і формування нового рівноважного стану. Обмеженням підходу $є$ його принципова неадаптивність - рівняння i зворотні зв'язки в моделях системної динаміки є структурними, вони формуються ще на етапі постановки задачі, тож можливість їх виникнення значною мірою контролюється варіацією значень параметрів моделі.
Для дослідження та моделювання процесу енергетичного переходу ми використали причиннонаслідкову та потокову діаграми. Причиннонаслідкові діаграми - головний інструмент системної динаміки - використовують для якісного аналізу процесів і систем, насамперед - для візуалізації проблеми, пошуку й апробації можливих рішень, залучення стейкхолдерів до деліберативного прийняття рішень (Rauschmayer \& Wittmer, 2006, Stave \& Kopainsky, 2015, Fedoruk \& Zahvoyska, 2018). Потокові діаграми використовують для кількісного аналізу. Їх формують на базі диференціальних рівнянь, які описують зміни потоків і запасів, і застосовують для аналізу характеру змін у системах за різних початкових умов 3 метою пошуку оптимальних рішень. Параметризацію потокової діаграми виконано за результатами регресійного аналізу макроекономічних даних.

Для розуміння та управління процесом переходу до сталого використання деревної біомаси в житловому секторі виконано SWOT-аналіз і запропоновано SWOT-стратегіï, для апробації яких використано причинно-наслідкову діаграму. Інструментальним середовищем моделювання слугувала програма AnyLogic (Karpov, 2009).

Результати та обговорення. Для візуалізації логіки виникнення і перебігу процесу енергетичного переходу ми побудували системно-динамічну модель, а саме - діаграму причинно-наслідкових зв'язків із петлями зворотного зв'язку (рис. 1). Ця модель складається 3 двох блоків: концептуального, який відображає логіку досліджуваного процесу, та операційного, який описує розвиток енергетичних кооперативів. Зв'язки між елементами цієї моделі показано стрілочками. Знак «+» означає прямий, посилюючий зв'язок між змінними $(\boldsymbol{R})$, а знак «-»- балансуючий $(\boldsymbol{B})$.

Перший блок причинно-наслідкової моделі відображає логіку виникнення зміни клімату та іiі подолання 3 використанням балансуючого зворотного зв'язку: усталене бачення причини зміни клімату полягає в неефективності домінуючої енергетичної парадигми та енергетичних систем, що призводить до надмірного використання викопного палива, викидів парникових газів, а відтак - у наростанні навантаження на довкілля. Що більші ці навантаження, то більш відчутна зміна клімату, iii вплив на добробут, зокрема безпеку населення (продовольчу, енергетичну та ін.), на розвиток таких галузей економіки, як сільське і лісове господарство, транспорт, страховий сектор тощо. Що більші ці екодеструкції, то більша увага національних урядів і міжнародних громадських організацій до причин виникнення цих змін. Ці запити знаходять відображення в наукових дослідженнях i, зрештою, через певний час приводять до ефективних рішень, зокрема: міжнародних угод, національних зобов'язань, правових та економічних інструментів, інформаційних заходів, освітніх програм тощо.

Цей балансуючий цикл можна розглядати як на національному, так і на регіональному (місцевому) 
рівнях, які відрізняються характером і масштабом заходів. Зокрема, на регіональному рівні йдеться про організаційно-економічні заходи, такі як регіональні програми, фонди, заходи самоорганізації громади для протидії викликам, наприклад, енергетичні кооперативи. Тож маємо дві балансуючі петлі в концептуальному блоці системнодинамічної моделі.

Другий блок моделі має операційний характер і дає змогу простежити процес формування і розвитку енергетичних кооперативів. У ньому показані акселератори росту (Karpov, 2009, Katalevsky, 2011), які описують ефект акумулювання знань і компетенцій, масштабу виробництва, а також поширення інновацій, як наприклад, створення енергетичних кооперативів. Це самопідсилювані зв'язки.

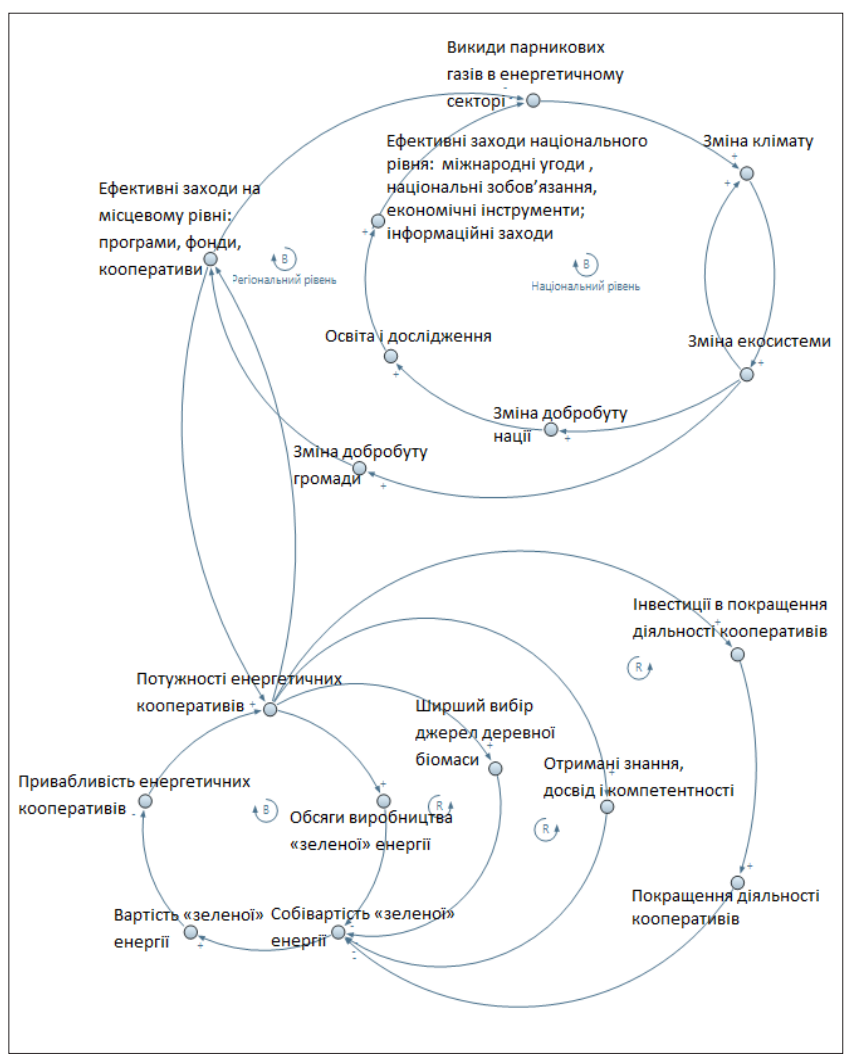

Рис. 1. Причинно-наслідкова діаграма процесу енергетичного переходу

Між обома розглянутими блоками цієї моделі існує зворотний зв'язок: самі кооперативи, які спеціалізуються на виробництві енергії з деревної біомаси, виникають внаслідок актуалізації проблеми енергетичного переходу, а їхнє успішне функціонування сприяє інтенсифікації цього процесу.

Для дослідження процесу формування кооперативів ми використали модель поширення інновацій (Bass, 1980) та модель системної динаміки інновацій (Sterman, 2000, Borshchev \& Filippov, 2004, Karpov, 2009, Katalevsky, 2011). Ця модель теж має два цикли: балансуючий, який описує насиченість ринку, та самопосилюваний, який описує інформування про інновації самими членами енергетичних кооперативів. Для балансуючого циклу врахована ефективність реклами, а для самопосилюваного кількість контактів, якість інституцій і самі позитивні відгуки.

Для параметризації цієї моделі проведено кореляційно-регресійний аналіз впливу інституціонально-економічних чинників на успішність енергетичних кооперативів. Для цього ми використали макроекономічні показники, запропоновані Світовим Економічним Форумом (WEF, 2018), які агреговані в індексі глобальної конкурентоспроможності і характеризують сприятливість середовища для ведення бізнесу, якість людського капіталу, ринки та екосистеми інновацій. За результатами кореляційного аналізу 311 макроекономічних показників (табл. 1) було відібрано ті, які мали найвищий коефіцієнт кореляції із залежною змінною Ү:

$\mathrm{Y}$ - наявність енергетичних кооперативів: 1 - наявні; 0 - відсутні;

X1 - інституції (частота появи фактів корупції, захист інтелектуальної власності, якість управління земельними ресурсами, надійність служб поліції і т. ін.);

Х2 - ринок збуту (конкуренція у сфері послуг, поширеність нетарифних бар'єрів, складність тарифів, відкритість торгівлі послугами);

X3 - фінансова система (ринкова капіталізація, кредитний дефіцит, наявність венчурного капіталу i т. ін.);

X4 - інноваційні можливості (різноманітність робочої сили, співпраця з багатьма сторонами, наукові публікації, патентні заявки і т. ін.).

Для створення бази даних дослідження ми відібрали країни-сусіди України, які мають подібний досвід формування енергетичної політики та інституціональні особливості, насамперед - країни Вишеградської четвірки, а також країни 3 досвідом створення енергетичних кооперативів: Австрія, Великобританія, Данія, Німеччина, США, Швеція, Естонія, Іспанія. Результати дескриптивного аналізу цих даних (табл. 2) відображають скромний успіх України у формуванні бізнес-середовища.

Методом найменших квадратів побудовано статистично значущу $(p>0,99)$ багатофакторну регресійну модель (1), однак жоден із іiі регресорів не був статистично значущим навіть 3 імовірністю $p \geq 0,9$ :

$$
\begin{gathered}
\mathrm{y}=0,041 * \mathrm{X} 1-0,045 * \mathrm{X} 2-0,008 * \mathrm{X} 3+0,021 * \mathrm{X} 4+0,046 \quad(1) \\
(1,573) \quad(-1,062) \quad(-0,361) \quad(1,158) \quad(0,028) \\
\mathrm{F}_{\text {розрах }}=6,155 ; \mathrm{F}_{0,95 ; 4 ; 11}=3,357 ; \mathrm{R}^{2}=0,691 \\
\mathrm{t}_{0,9 ; 16-4-1}=3,106 .
\end{gathered}
$$

Застосувавши покроковий метод для уникнення мультиколінеарності, отримуємо парну регресійну модель (2):

$$
\begin{gathered}
\mathrm{y}=0,0397^{*} \mathrm{X}_{1}-1,9737 . \\
(4,9801) \quad(-3,83) \\
\mathrm{F}=24,8 ; \mathrm{R}_{\text {скориг }}^{2}=0,61 ; \mathrm{t}_{0,95 ; 16-1-1}=2,14
\end{gathered}
$$


Таблиия 1

Макроекономічні показники, які формують індекс глобальної конкурентоспроможності країн 4.0

\begin{tabular}{|c|c|c|c|c|c|c|c|c|c|c|c|c|}
\hline 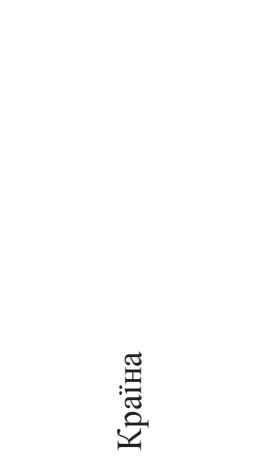 & 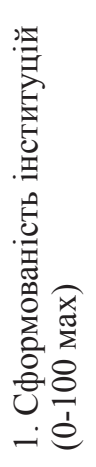 & 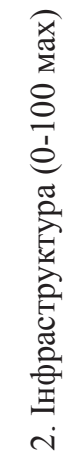 & 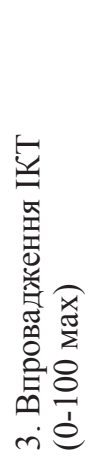 & 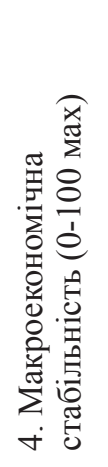 & 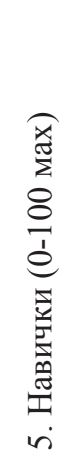 & 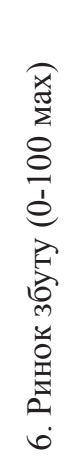 & 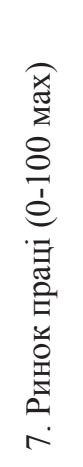 & 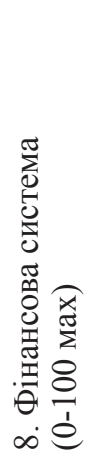 & 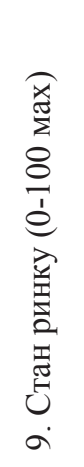 & 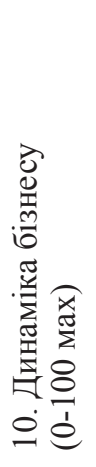 & 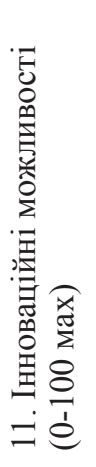 & 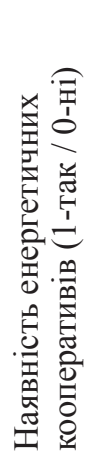 \\
\hline & $\mathrm{X} 1$ & - & - & - & - & $\mathrm{X} 2$ & - & X3 & - & - & $\mathrm{X} 4$ & Y \\
\hline Австрія & 72,7 & 88,3 & 64,7 & 100,0 & 78,4 & 66,5 & 67,3 & 72,9 & 64,3 & 69,9 & 74,3 & 1 \\
\hline Албанія & 53,9 & 57,3 & 52,3 & 70,0 & 68,7 & 57,0 & 68,4 & 51,3 & 39,2 & 64,1 & 31,7 & 0 \\
\hline Великобританія & 77 & 89 & 71 & 100,0 & 80,0 & 69,0 & 76,0 & 88,0 & 82,0 & 79,0 & 79,0 & 1 \\
\hline Данія & 75,9 & 86,3 & 82,3 & 100,0 & 84,9 & 66,9 & 78 & 85,8 & 59,6 & 79,1 & 75,4 & 1 \\
\hline Естонія & 70,0 & 75,0 & 77,0 & 100,0 & 78,0 & 65,0 & 69,0 & 66,0 & 42,0 & 69,0 & 53,0 & 1 \\
\hline Іспанія & 64,0 & 89,0 & 74,0 & 90,0 & 71,0 & 62,0 & 59,0 & 75,0 & 77,0 & 66,0 & 63,0 & 1 \\
\hline Німеччина & 73,5 & 90,2 & 69,3 & 100,0 & 85,4 & 72 & 74,1 & 80,2 & 85,8 & 81,6 & 87,5 & 1 \\
\hline Польща & 57,1 & 79,3 & 54,4 & 100,0 & 72,9 & 61,2 & 59,8 & 63,4 & 73,4 & 61,5 & 48,7 & 0 \\
\hline Румунія & 58,1 & 71,2 & 67,1 & 89,2 & 61,8 & 57,3 & 60,7 & 51,9 & 64,7 & 60,1 & 39,6 & 0 \\
\hline Сербія & 51,6 & 73 & 56,9 & 75,0 & 67,5 & 56,5 & 61,5 & 55,9 & 50,7 & 60,9 & 39,7 & 0 \\
\hline Словаччина & 56,4 & 77,6 & 67,8 & 99,9 & 68,6 & 55 & 60,2 & 63,7 & 57,7 & 64,5 & 46,6 & 0 \\
\hline США & 74,6 & 89,5 & 71,2 & 99,6 & 86,3 & 73,8 & 81,9 & 92,1 & 99,2 & 86,5 & 86,5 & 1 \\
\hline Угорщина & 54,0 & 78,0 & 61,0 & 90,0 & 68,0 & 54,0 & 58,0 & 60,0 & 62,0 & 57,0 & 48,0 & 1 \\
\hline Україна & 46,3 & 70,1 & 51,0 & 55,9 & 68,9 & 55,3 & 59,5 & 48,7 & 62,7 & 55,3 & 39,0 & $\mathbf{0}$ \\
\hline Чехія & 60,0 & 84,0 & 66,0 & 100,0 & 74,0 & 60,0 & 63,0 & 67,0 & 65,0 & 70,0 & 57,0 & 0 \\
\hline Швеція & 76,0 & 84,0 & 85,0 & 100,0 & 84,0 & 69,0 & 71,0 & 89,0 & 65,0 & 80,0 & 80,0 & 1 \\
\hline
\end{tabular}

Джерело даних: WEF (2018).

Таблиия 2

Описова статистика початкових даних дослідження впливу факторів на формування енергетичних кооперативів

\begin{tabular}{lccccc}
\hline \multicolumn{1}{c}{ Назва } & $\begin{array}{c}\text { Сформованість } \\
\text { інституцій } \\
(0-100 \text { мах })\end{array}$ & $\begin{array}{c}\text { Ринок збуту } \\
(0-100 \text { мах })\end{array}$ & $\begin{array}{c}\text { Фінансова } \\
\text { система } \\
(0-100 \text { мах })\end{array}$ & $\begin{array}{c}\text { Інноваційні } \\
\text { можливості } \\
(0-100 \text { мах })\end{array}$ & $\begin{array}{c}\text { Наявність енергетичних } \\
\text { кооперативів } \\
(1-\text { так, 0 - ні) }\end{array}$ \\
\hline \multicolumn{1}{c}{1} & $\mathrm{X} 1$ & $\mathrm{X} 2$ & $\mathrm{X} 3$ & $\mathrm{X} 4$ & $\mathrm{Y}$ \\
Середнє значення & 2 & 3 & 4 & 5 & 6 \\
Станд. похибка & 63,82 & 62,53 & 69,43 & 59,31 & 0,56 \\
Медіана & 2,58 & 1,61 & 3,59 & 4,67 & 0,13 \\
Мода & 62,00 & 61,60 & 66,50 & 55,00 & 1,00 \\
Станд. відхилення & - & 69,00 & - & - & 1,00 \\
Дисперсія & 10,31 & 6,46 & 14,36 & 18,69 & 0,51 \\
\hline
\end{tabular}


Продовж. табл. 2

\begin{tabular}{lccccc}
\hline \multicolumn{1}{c}{1} & 2 & 3 & 4 & 5 & 6 \\
\hline Ексцес & $-1,54$ & $-1,27$ & $-1,26$ & $-1,48$ & $-2,22$ \\
Асиметрія & $-0,08$ & 0,28 & 0,19 & 0,20 & $-0,28$ \\
Діапазон & 30,70 & 19,80 & 43,40 & 55,80 & 1,00 \\
Мінімум & $\mathbf{4 6 , 3 0}$ & $\mathbf{5 4 , 0 0}$ & $\mathbf{4 8 , 7 0}$ & $\mathbf{3 1 , 7 0}$ & $\mathbf{0 , 0 0}$ \\
Максимум & 77,00 & 73,80 & 92,10 & 87,50 & 1,00 \\
Україна & $\mathbf{4 6 , 3}$ & $\mathbf{5 5 , 3}$ & $\mathbf{4 8 , 7}$ & $\mathbf{3 9 , 0}$ & $\mathbf{0}$ \\
\hline
\end{tabular}

Джерело: авторські розрахунки за (WEF, 2018)

3 імовірністю $p=0,95$ вона показує, що лише змінна X1 - ефективність інституцій - $є$ статистично значущим чинником успішності енергетичних кооперативів: покращення якості діяльності інституцій на один пункт підвищує успішність кооперативів на чотири пункти. Тож цю змінну (X1) потрібно врахувати в потоковій діаграмі (рис. 2). Однак, нагадаємо, що за цим показником Україна має дуже слабку позицію (див. табл. 2): 110-те місце в рейтингу 140 країн.

Позиціонування аналізованих країн за двома ознаками: сформованість інституцій (X1) і наявність енергетичних кооперативів (Y) відносно середніх значень цих величин (див. табл. 2) показало наявність трьох кластерів:

1) країни з середнім ( Іспанія) і вище від середнього (Естонія, Австрія, Німеччина, США, Данія, Швеція і Великобританія) рівнями розвитку інституцій. В усіх цих країнах енергетичні кооперативи успішні;

2) країни $з$ рівнем розвитку інституцій нижче від середнього (Чехія, Румунія, Польща, Словаччина, Албанія, Сербія та Україна), в яких енергетичні кооперативи відсутні або слабкі;

3) і лише Угорщина $з$ рівнем сформованості інституцій нижче від середнього має позитивний досвід функціонування енергетичних кооперативів.

Тож енергетичні кооперативи - це той ефективний інструмент, який трансформує довіру економічних агентів та якісне бізнес-середовище у дієвий механізм переходу до більш децентралізованої й екологізованої моделі енергетичної системи, яка використовує насамперед місцеві ресурси і забезпечує задоволення енергетичних потреб місцевих громад. У разі відмови від викопного палива і переходу до сталого використання біомаси енергетичний кооператив може отримати додаткові вигоди: від можливості отримання безвідсоткової позики чи гранту - до «зеленого тарифу» за вироблену електроенергію і тепло. I такі вигоди можуть бути суттєвими.

Керуючись дослідженнями інших учених i результатами власних досліджень, проведених у м. Борислав, ми прийняли такі значення для параметрів потокової моделі (див. рис. 2): 8,5 тис. потенційних членів кооперативів-власників житлових приміщень; коефіцієнт урахування впливу джерел заохочення становив 0,011 , позитивних відгуків - 0,015; вплив інституцій за результатами регресійного аналізу оцінили як 0,039 ; прийняли, що між членами кооперативів і потенційними учасниками відбувається 25 контактів щороку.

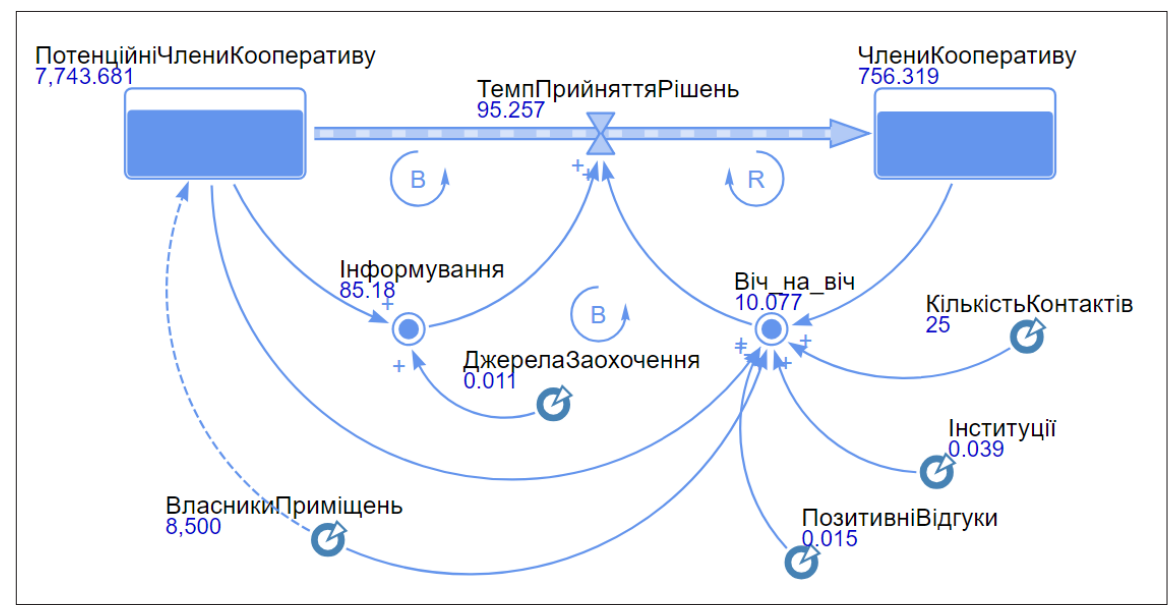

Рис. 2. Параметризована потокова діаграма моделі поширення екоінновацій.

Час моделювання - 8 років; коефіцієнт впливу джерел заохочення 0,011

Джерело: авторська розробка за (Bass, 1980, Sterman, 2000, Borshchev\&Filippov, 2004, Karpov, 2009, Katalevsky, 2011) 
Розвиток кооперативів описує змінна ТемпПрийняттяРішень. За результатами моделювання бачимо, що через 8 років кількість членів кооперативів складатиме лише 756 осіб, тобто 8,9\% власників помешкань міста. Це означає, що інформування через джерела заохочення чинитиме більший вплив на процес прийняття рішень, ніж відгуки членів енергетичних кооперативів. Таку ситуацію можна пояснити тим фактом, що сам процес переходу відбувається повільно, насамперед - через неефективність інституцій. Разом із тим, за результатами проведеного нами опитування населення м. Борислав 18,1\% респондентів знайомі з концепцією енергетичних кооперативів, а $21,7 \%$ цих респондентів готові вкласти власні кошти в їхній розвиток. Близько половини опитаних $(44,6 \%)$ бажають змінити системи опалення у своїх помешканнях, що значно простіше зробити членам кооперативів. 8,3\% респондентів вважають ефективним використання дров для опалення. Деякі респонденти прямо вказували на неефективність інституцій як передумову млявого перебігу процесу створення енергокооперативів.

Зазначимо, що довіра до державних і громадських інституцій, прозорість і передбачуваність їхньої економічної поведінки є важливими передумовами для формування енергетичних кооперативів, які зможуть без патерналістичного сподівання на державу забезпечувати себе та інших енергетичними ресурсами і послугами, створюючи при цьому «зелені» робочі місця і нову якість життя.

Отже, результати моделювання та опитування показують зацікавленість і принципову можли- вість реалізації ідеї енергетичних кооперативів в інституціональному макросередовищі України. Проте процес їхнього формування відбувається доволі мляво. Тож для розуміння рушіїв і перешкод цього процесу ми провели SWOT-аналіз (Rauch et al., 2015), результати якого (табл. 3) стали підгрунтям для формування SWOT-стратегій розвитку досліджуваного процесу.

Для перевірки обгрунтованості й ефективності запропонованих SWOT-стратегій ми використали причинно-наслідкову модель процесу енергетичного переходу (див. рис. 1), яка послужила інструментом для пошуку відповідей на тестові запитання типу «what-if» (Bennich et al., 2018, Fedoruk \& Zahvoyska, 2018). Результати цього моделювання (табл. 4), яке забезпечило цілісне охоплення різноманіття взаємовпливів ідентифікованих процесів, дали змогу виявити перешкоди, які можуть виникнути у запропонованих нами SWOTрекомендаціях, їхні потенційні небажані наслідки, невизначеність, яку потрібно ще дослідити, а також запропонувати додаткові важелі впливу на процес.

Виявлені небажані можливі наслідки запропонованих рекомендацій потребують окремого аналізу і прийняття рішень для їх запобігання, оскільки вони можуть заблокувати процес. Особливої уваги у цьому контексті потребують питання забезпечення відповідності вимогам сталого лісокористування. Запропоновані додаткові важелі впливу $\epsilon$ iнструментом спрямування енергетичного переходу в бажаному напрямі.

Таблиця 3

\section{Результати SWOT-аналізу практики використання деревної біомаси на прикладі м. Борислав}

\begin{tabular}{|c|c|c|}
\hline & Сильні позиції (Strengths) & Слабкі позиції (Weaknesses) \\
\hline \multirow[t]{2}{*}{ 志 } & 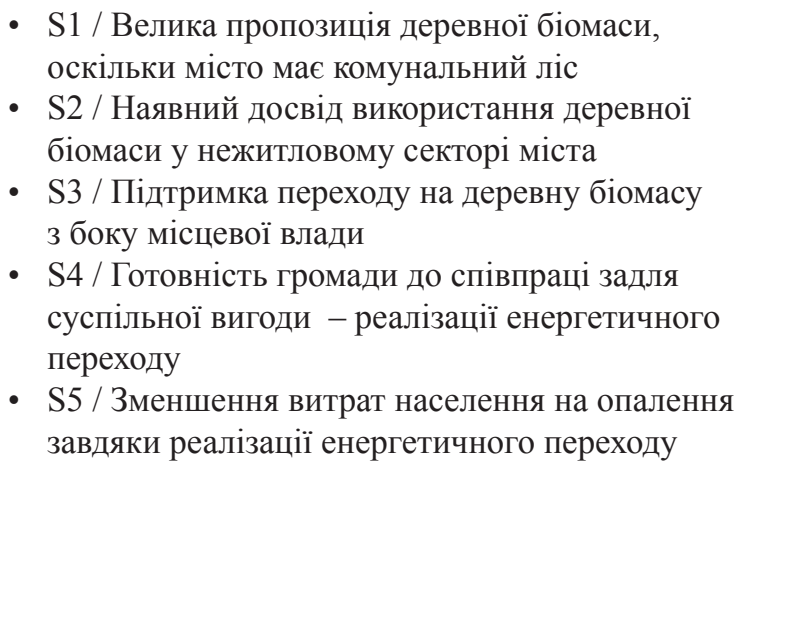 & 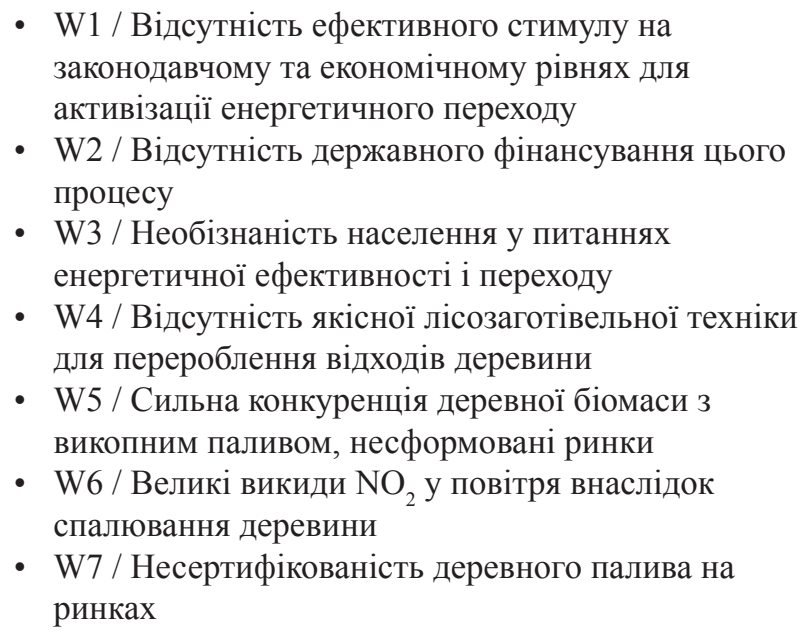 \\
\hline & Можливості (Opportunities) & Загрози (Threats) \\
\hline $\begin{array}{l}\text { 目 } \\
\text { 罾 } \\
\text { ले }\end{array}$ & $\begin{array}{l}\text { - } \text { О1 / Посилення тенденцій процесу енергетичного } \\
\text { переходу в світі } \\
\text { - О2 / Світовий досвід функціонування } \\
\text { енергетичних кооперативів і проектів } \\
\text { - } \text { О3 / Поява технологій і бізнес-моделей ефективної } \\
\text { утилізації деревних відходів }\end{array}$ & $\begin{array}{l}\text { • } \text { Т1 / Велика пропозиція дешевого супутнього газу } \\
\text { • } 2 \text { / Загроза надмірного використання } \\
\text { деревних ресурсів } \\
\text { • } 33 \text { / Невпевненість населення в дієвості } \\
\text { енергетичних кооперативів }\end{array}$ \\
\hline
\end{tabular}


Продовж. табл. 3

- О4 / Залучення зарубіжних інвесторів до енергетичного переходу в Україні

- О5 / Більша площа комунального лісу

- О6 / Розгортання місцевого виробництва деревних пелет і брикетів

- 07 / Зростання обсягів споживання пелет місцевого виробництва (м. Дрогобич)

- 08 / Комбінування деревної біомаси з іншими відновлюваними джерелами енергії
- Т4 / Відсутність коштів у населення

- Т5 / Наявність субсидій на опалення, які перешкоджають реалізації переходу на відновні джерела енергії

- 66 / Підвищення ціни на деревину

- Т7 / Конкуренція в доступі до енергетичної деревини

- $\mathrm{T} 8$ / Виникнення нових енергетичних технологій i альтернативного використання деревини

Джерело: авторська розробка за результатами опитування.

Варті особливої підтримки виникаючі синергії у покращенні якості різних форм капіталу. Пильнішу увагу потрібно звернути на вимушені компроміси ресурсокористування, причини й умови їх досягнення. Визначальними чинниками успішної реалізації переходу постають суб’єктність стейкхол- дерів, їхня готовність діяти, знання і вміння, а також ефективність інституцій і взаємоузгодженість влади, декларованої нею відповідальності і реальних дій. Ці висновки узгоджуються з результатами досліджень інших учених (Stirling, 2014).

Табличя 4

Тестування SWOT-стратегій покращення використання деревної біомаси в житловому секторі м. Борислав з увагою на енергетичні кооперативи

\begin{tabular}{|c|c|c|c|c|}
\hline $\begin{array}{c}\text { Запитання для } \\
\text { тестування } \\
\text { рекомендованих } \\
\text { заходів }\end{array}$ & $\begin{array}{l}\text { Бажаний } \\
\text { результат }\end{array}$ & $\begin{array}{c}\text { Потенційні небажані } \\
\text { наслідки }\end{array}$ & $\begin{array}{c}\text { Додаткові важелі } \\
\text { впливу }\end{array}$ & $\begin{array}{c}\text { Невизначеності та } \\
\text { приклади пов'язаних } \\
\text { запитань }\end{array}$ \\
\hline
\end{tabular}

$\begin{array}{lllll}1 & 2 & 3 & 4 & 5\end{array}$

Рекомендація 1. Агресивна, SO стратегія. Використання власного досвіду і потенціалу, а також ресурсів міжнародних програм і фондів для забезпечення правової, економічної та інформаційної підтримки енергетичного використання деревної біомаси в житловому секторі міста 3 узгодженням економічних, соціальних та екологічних цілей, зокрема і шляхом створення енергетичних кооперативів

1. Що дасть синергія цих зусиль і ресурсів?

$$
\begin{aligned}
& \text { - Часткова реалізація } \\
& \text { цілей енергетичного } \\
& \text { переходу }
\end{aligned}
$$

- Через зниження
ціни «зеленої»
енергії може зрости
споживання
- Низька якість
інституцій може
унеможливити
виникнення
кооперативів

- Державне стимулювання і фінансова підтримка

- Міжнародна підтримка
- Чи будуть стійкими ці кооперативи в майбутньому, коли закінчаться проекти чи гранти?

Рекомендація 2. Конкурентна, WO-стратегія. Формування ринкової та консультаційної інфраструктури, розроблення і запровадження екоінноваційних (кооперативних) бізнес-моделей і технологій ефективнішого використання деревних відходів у житловому секторі

2. Що дасть формування цієї інфраструктури?

$$
\begin{aligned}
\text { - Конкурентний доступ } \\
\text { до біомаси } \\
\text { - «Зелені» робочі } \\
\text { місця } \\
\text { - Виконання } \\
\text { міжнародних } \\
\text { зобов’язань Україною }
\end{aligned}
$$

- Відсутність
державного
фінансування
ускладнить перехід
- Значні обсяги
споживання деревної
біомаси збільшать
викиди $\mathrm{NO}_{2}$

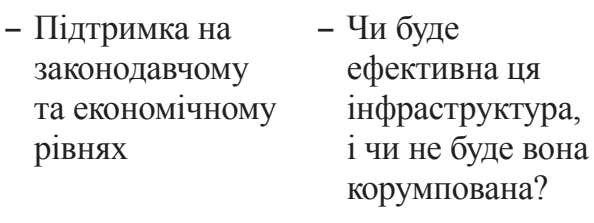

- Підтримка на законодавчому та економічному рівнях
- Чи буде ефективна ця інфраструктура, і чи не буде вона корумпована?


Продовж. табл. 4 2 3 4 5

\section{Рекомендація 3. Консервативна, ST-стратегія. Сприяння співпраці держави і громади в питаннях} активізації процесу енергетичного переходу

$\begin{array}{lcclc}\text { 3. Що дасть } & \text { - Синергія інтересів } & - \text { Можливе надмірне } & - \text { Спілкування } & \text { - Чи змінить громада } \\ \text { залучення } & \text { громади і держави } & \text { використання лісових } & \text { зацікавлених } & \text { своє рішення, } \\ \text { громади } & \text { - Деліберативне } & \text { ресурсів } & \text { осіб, краще } & \text { досягнувши мети? } \\ \text { до процесу } & \text { прийняття рішень } & & \text { розуміння } & \\ \text { енергетичного } & & \text { iнтересів інших }\end{array}$
переходу?

Рекомендація 4. Запобіжна, WT-стратегія. Екологізація економічної, освітньої і наукової діяльності, коригування системи цінностей, критеріїв та інститутів

$\begin{array}{llccc}\text { 4. Що дадуть } & \text { - Холістичне розуміння } & \text { - Відсутність попиту } & \text { - Обізнаність } & \text { - Обмін досвідом } \\ \text { процеси } & \text { і вирішення проблеми } & \text { на деревну біомасу } & \text { населення сприяє } & \text { з кооперативами } \\ \text { екологізації } & \text { енергетичного } & \text { через високі ціни } & \text { ефективності } & \text { в інших регіонах } \\ \text { економіки та } & \text { переходу } & & \text { його діяльності } & \end{array}$
освіти?

Джерело: авторська розробка за результатами SWOT-аналізу і моделювання.

Висновки. У сучасному соціо-еколого-економічному контексті для України пріоритетним завданням є здійснення енергетичного переходу, одним із аспектів якого є забезпечення енергетичного використання деревної біомаси у житловому секторі на засадах сталості. Проте цей процес має дифузний характер і зачіпає низку взаємопов'язаних процесів у різних сферах життєдіяльності: соціальній, екологічній, економічній, технічній, освітній та ін. Тому моделювання цього процесу потребує холістичного розуміння складної динаміки ініційованих змін і відповідних інструментів їі дослідження, одним із яких є системна динаміка.

Запропоновані нами елементи механізму організаційно-економічного забезпечення - причинно-наслідкова діаграма процесу енергетичного переходу та потокова діаграма процесу формування енергетичних кооперативів - виявилися ефективними для ідентифікації, візуалізації та системного аналізу нексусу енергетичного переходу. Набутий досвід побудови цих моделей підказує, що ці моделі легко піддаються деталізації та коригуванню, відображають (конфліктуючі) позиції стейкхолдерів і забезпечують підгрунтя для застосування деліберативних методів прийняття рішень, що важливо для вирішення проблем на засадах постнекласичної наукової парадигми.

Здійснений аналіз показав складність досліджуваного процесу і різноманіття шляхів його імплементації, недостатність та обмеженість технологічних рішень. Для розуміння цінності запропонованих рішень важливо врахувати той факт, що запропоновані SWOT-стратегії інтенсифікації процесу енергетичного переходу можуть створювати ефекти синергії 3 іншими заходами, або блокувати бажані зміни. Тому невизначеність, притаманна досліджуваним процесам і системам, забезпечує широке поле для подальших досліджень шляхів і засобів забезпечення енергетичного переходу в житловому секторі, можливо, з використанням запропонованих нами системно-динамічних моделей, які виявилися ефективними засобами пізнання та управління.

Acknowledgement. The research were conducted under the Swiss-Ukrainian project «Identifying Green Energy Options for the Ukrainian Carpathians from a biophysical and socioeconomic perspective», funded by the Swiss Secretariat for Research, Education and Innovation and run by Swiss Federal Institute for Forest, Snow and Landscape Research WSL and Ukrainian National Forestry University.

\section{References}

Bass, F. M. (1980). The relationship between diffusion rates, experience curves, and demand elasticities for consumer durable technological innovations. Journal of business, 53 (3), 51-67. http://0021-9398/80/5332$0009 \$ 01.50$

Bauwens, T., Gotchev, B., \& Holstenkamp, L. (2016). What drives the development of community energy in Europe? The case of wind power cooperatives. Energy Research \& Social Science, 13, 136-147. https://doi.org/10.1016/j.erss.2015.12.016

Bennich, T., Belyazid, S., Kopainsky, B., \& Diemer, A. (2018). The bio-based economy: Dynamics governing transition pathways in the Swedish forestry sector. Sustainability, 10 (4), 976. https://doi.org/10.3390/ su10040976

Borshchev, A., \& Filippov, A. (2004, July). From system dynamics and discrete event to practical agent based modelling: reasons, techniques, tools. In Proceedings of the 22nd international conference of the system dynamics society (Vol. 22). Oxford, 
England. http://citeseerx.ist.psu.edu/viewdoc/downl oad?doi=10.1.1.511.9644\&rep=rep1\&type $=$ pdf

Bouzarovski, S., \& Tirado Herrero, S. (2017). The energy divide: Integrating energy transitions, regional inequalities and poverty trends in the European Union. European Urban and Regional Studies, 24 (1), 6986. https://doi.org/10.1177/0969776415596449

Bridge, G., Bouzarovski, S., Bradshaw, M., \& Eyre, N. (2013). Geographies of energy transition: Space, place and the low-carbon economy. Energy policy, 53, 331340. https://doi.org/10.1016/j.enpol.2012.10.066

Droege, P. (Ed.) (2011). Urban energy transition: From fossil fuels to renewable power. Elsevier: Amsterdam, Boston, Heidelberg, London ...

Ericsson, K., \& Werner, S. (2016). The introduction and expansion of biomass use in Swedish district heating systems. Biomass and bioenergy, 94, 57-65. https://doi.org/10.1016/j.biombioe.2016.08.011

Fedoruk, M., \& Zahvoyska, L. (2018). Modeling the process of ecologization investments in energy saving in residential and public buildings of cities by using the method of system dynamics. Journal of European Economy, 17 (3), 333-345. https://doi.org/10.35774/ jee2018.03.333

Grigoryeva, A., Hesamzadeh, M.R., \& Tangeras, T. (2018). Energy System Transition in the Nordic Market: Challenges for Transmission Regulation and Governance. Economics of Energy \& Environmental Policy, 7 (1), 127-147. https://doi.org/10.5547/21605890.7.1.agri

Hansen, J., \& Sato, M. (2016). Regional climate change and national responsibilities. Environmental Research Letters, 11 (3), 034009. https://iopscience. iop.org/article/10.1088/1748-9326/11/3/034009

Hansen, J., Sato, M., Hearty, P., Ruedy, R., Kelley, M., Masson-Delmotte, V., ... \& Velicogna, I. (2016). Ice melt, sea level rise and superstorms: evidence from paleoclimate data, climate modelling, and modern observations that $2 \mathrm{C}$ global warming could be dangerous. Atmospheric Chemistry and Physics, 16 (6), 3761-3812. https://doi.org/10.5194/acp-163761-2016

Havrysh, V.I. (2008). Economic bases of formation of agricultural cooperatives of fuel and energy orientation. AgroInKom, 1-2, 40-44 (in Uktainian).

Hoppe, T., Graf, A., Warbroek, B., Lammers, I., \& Lepping, I. (2015). Local governments supporting local energy initiatives: Lessons from the best practices of Saerbeck (Germany) and Lochem (The Netherlands). Sustainability, 7 (2), 1900-1931. https:// doi.org/10.3390/su7021900.

Karpov, Yu. G. (2009). Simulation of systems. Introduction to modelling with AnyLogic 5 BHVPeterburg, St.Petersburg (in Russian).

Katalevsky, D.Y. (2011) The fundamentals of simulation and systems analysis in management. Moscow: Moscow University (in Russian).

Loorbach, D. (2010). Transition management for sustainable development: a prescriptive, complexity- based governance framework. Governance, 23 (1), 161-183. http://transitionacademy.nl/content/ uploads/2016/07/Literatuur-Derk-Loorbach-7Transition-management-for-sustainable-developmenta-prescriptive-complexity-based-governanceframework.pdf

McGinnis, M., \& Ostrom, E. (2014). Social-ecological system framework: initial changes and continuing challenges. Ecology and Society, 19 (2). http://dx.doi. org/10.5751/ES-06387-190230

Meadows, D.H., Meadows, D.L., Randers, J., \& Behrens, W.W. (1972). The limits to growth. New York: Universe Books

Moss, T., Becker, S., \& Naumann, M. (2015). Whose energy transition is it, anyway? Organisation and ownership of the Energiewende in villages, cities and regions. Local Environment, 20 (12),1547-1563. https://doi.org/10.1080/13549839.2014.915799

Pastukh, A. (2016). Creation of energy co-operatives in Ukraine: legal aspects. Presentation at the seminar «Bioenergy village - energy independence at the local level», 18.02.2016, Kyiv. http://saee.gov.ua/ sites/default/files/6_EC_Pastukh.pdf (in Ukrainian).

Prokop, A.V. (2010). Part greek catholic church in building operative institutions Galicia late nineteenthearly twentieth century. Herald of LUTE, 9, 122-129 (in Ukrainian).

Rauch, P., Wolfsmayr, U.J., Borz, S.A., Triplat, M., Krajnc, N., Kolck, M., ... \& Mühlberg, C. (2015). SWOT analysis and strategy development for forest fuel supply chains in South East Europe. Forest Policy and Economics, 61, 87-94. http://dx.doi. org/10.1016/j.forpol.2015.09.003

Rauschmayer, F., \& Wittmer, H. (2006). Evaluating deliberative and analytical methods for the resolution of environmental conflicts. Land Use Policy, 23 (1), 108-122. https://doi.org/10.1177/ 0734242 X06063817

Schreuer, A., \& Weismeier-Sammer, D. (2010). Energy cooperatives and local ownership in the field of renewable energy technologies: A literature review. Available at: https://epub.wu.ac.at/id/eprint/2897

Simon, H.A. (1997). Models of bounded rationality: Empirically grounded economic reason (vol. 3). MIT Press, London.

Solomon, B.D., \& Krishna, K. (2011). The coming sustainable energy transition: History, strategies, and outlook. Energy Policy, 39 (11), 7422-7431. 10.1016/j.enpol.2011.09.009

Stave, K.A., \& Kopainsky, B. (2015). A system dynamics approach for examining mechanisms and pathways of food supply vulnerability. Journal of Environmental Studies and Sciences, 5 (3), 321-336. https://doi.org/10.1007/s13412-015-0289-x

Steffen, W.L., Rockström, J., \& Costanza, R. (2011). How defining planetary boundaries can transform our approach to growth. Solutions: For a Sustainable \& Desirable Future, 2 (3), 59-65. Available at: http:// pdxscholar.library.pdx.edu/iss_pub 
Sterman, J. (2000) Business Dynamics: Systems Thinking and Modeling for a Complex World. Boston; Irwin /McGraw-Hill.

Stirling, A. (2014). Transforming power: Social science and the politics of energy choices. Energy Research \& Social Science, 1, 83-95. https://doi.org/10.1016/j. erss.2014.02.001

Stoyko, O. M. (2018). Energy cooperatives as the main form of civil society participation in energy transit. Hileya: Scientific Bulletin, 136, 233-235. http://www. irbis-nbuv.gov.ua/cgi- bin/irbis nbuv/cgiirbis 64.ex $\mathrm{e} ? \mathrm{C} 21 \mathrm{COM}=2 \& \mathrm{I} 21 \mathrm{DBN}=\mathrm{UJR} \mathrm{R} \& \mathrm{P} 21 \mathrm{DBN}=\mathrm{UJR}$ N\&IMAGE FILE DOWNLOAD=1\&Image file name=PDF/gileya_2018_136_57.pdf (in Ukrainian).

Van der Kroon, B., Brouwer, R., \& Van Beukering, P. J. (2013). The energy ladder: Theoretical myth or empirical truth? Results from a meta-analysis. Renewable and Sustainable Energy Reviews, 20, 504513. http://dx.doi.org/10.1016/j.rser.2012.11.045

WEF'(2018). Global Competitiveness Report. Available at: http://reports.weforum. org/globalcompetitiveness-report-2018/country-economyprofiles

Zahvoyska, L.D. (2005). Recent trends in ecological economics investigations. Scientific Bulletin of UNFU, 15 (6), 136-143 https://cyberleninka. $\mathrm{ru} / \mathrm{article} / \mathrm{n} / \mathrm{prioritetni-napryamki-naukovih-}$ doslidzhen-ekologichnoyi-ekonomiki (in Ukrainian).

Zahvoyska, L.D. (2013). Theoretical approaches to modeling dynamics of ecological and economic systems. Modeling of the Regional Economy, 2, 85102. http://nbuv.gov.ua/j-pdf/Modre 20132 10.pdf (in Ukrainian).

Zahvoyska, L.D. (2014). Conceptualizing of ecoinnovations in the context of recent ecologicaleconomic discourse. Odesa National University Herald. Series Economy, 19 (2/5), 17-20. http:// visnyk-onu.od.ua/journal/2014_19_2_5/04.pdf (in Ukrainian).

Zahvoyska, L.D., Lazor, O. Ya, \& Lazor, O.D. (2007). Approaches and techniques of environmental impact assessment. Economy of Ukraine, 3, 80-89. (in Ukrainian).

Zahvoyska, L.D., Pelyukh, O.R. (2019). Epistemological instruments for ecologicaleconomic systems investigations. Proceedings of the Forestry Academy of Sciences of Ukraine, 18, 154163. https://doi.org/10.15421/411916 (in Ukrainian).

Zinchenko, A. (2013). Energy cooperatives and their opportunities for distribution in Ukraine. Retrieved from http:/www.biowatt.com.ua/trends/ energetichni-kooperativi-ta-mozhlivosti-yihposhirennya-v-ukrayini (in Ukrainian).

\section{Моделирование процесса энергетического перехода с использованием системной динамики: энергетические кооперативы как инструмент перехода к устойчивому использованию древесной биомассы в жилом секторе}

\author{
Л.Д. Загвойска', О. В. Блецка²
}

\section{Доминирующая парадигма производства} энергии является высокоцентрализованной, углеродоемкой и способствует существованию энергетической бедности. Императив глобального изменения климата актуализирует энергетический переход для обеспечения эффективности, инклюзивности и экологической безопасности процессов производства энергии. Одним из аспектов этого процесса является переход к устойчивому использованию древесной биомассы в жилом секторе с использованием энергетических кооперативов в качестве средства содействия процессу перехода. Этот процесс связан с нексусом изменений, вызванных в таких сферах, как социальная, экологическая, экономическая, технологическая, образовательная и т. д. Противоречивая динамика процессов может создать синергии или потребовать компромиссов.

Чтобы охватить сложность процесса перехода, мы разработали и применили модели системной динамики. Причинно-следственная диаграмма переходного процесса использована для понимания процесса. Модель состоит из двух блоков: концептуального, описывающего общую логику смягчения изменений климата, и операционного, описывающего развитие энергетических кооперативов.

Для количественного анализа процесса развития энергетических кооперативов предложена диаграмма потоков и накопителей. Эта диаграмма основана на модели распространения инноваций Басса (1980) и модели системной динамики Стермана (2000). Диаграмма параметризирована в соответствии с реалиями г. Борислава. Особенности украинского институционального ландшафта изучены с использованием регрессионного анализа 11 показателей, агрегированных в индексе глобальной конкурентоспособности 4.0 (WEF, 2018). Согласно результатам анализа, дополнена диаграмма потоков и накопителей параметром институции, описывающим зависимость экономической активности индивидов

\footnotetext{
Загвойска Людмила Дмитриевна - член-корреспондент Лесной академии наук Украины, кандидат экономических наук, доцент кафедры экологической экономики. Национальный лесотехнический университет Украины, ул. Генерала Чупрынки, 103, г. Львов, 79057, Украина. Тел.: +38-050-371-44-29. E-mail: 1yudmyla.zahvoyska@nltu.edu.ua ORCID: https://orcid. org/0000-0002-0028-4723

Блеика Ольга Васильевна - магистр экономики окружающей среды и природных ресурсов. Национальный лесотехнический университет Украины, ул. Генерала Чупрынки, 103, г. Львов, 79057, Украина. Тел.: +38-068-532-70-37; E-mail: olyakhust@ gmail.com ORCID: https://orcid.org/0000-0002-0467-8068
} 
от эффективности институций. Моделирование 8-летнего периода, выполненное с использованием параметризованной диаграммы, продемонстрировало довольно вялый переход к энергетическим кооперативам - только 8,9 \% домовладельцев, что можно объяснить неэффективностью институций Украины.

Однако, согласно опросу, который проведен в г. Борислав, с концепцией энергетических кооперативов знакомы $18,1 \%$ респондентов. Из них, каждый пятый был готов инвестировать в развитие кооперативов; около половины респондентов намерены изменить системы отопления в своих домах, что проще сделать членам кооперативов.

Чтобы получить представление об использовании древесной биомассы для г. Борислава, проведен SWOT-анализ и предложено четыре SWOTстратегии для управления процессом. Эти рекомендации изучены с помощью вопросов «что, если» с использованием предложенной нами модели процесса перехода, что позволило выявить возможные непреднамеренные последствия, неопределенности и дополнительные вмешательства, облегчающие понимание процесса и делиберативное принятие решений по управлению процессом энергетического перехода.

Ключевые слова: трансформация энергетических систем; кооперативная бизнес-модель; SWOT-анализ и стратегии; регрессионный анализ; причинно-следственная и поточная диаграммы, делиберативные методы принятия решений.

\section{Modelling Energy Transition Process using System Dynamics: Energy Cooperatives as a Tool for Transition to Sustainable Use of Wood Biomass in the Residential Sector}

\section{Zahvoyska', O. Bletska²}

Dominant energy generation paradigm is highly centralized, carbon intensive, and enable energy poverty. Global climate change imperative prioritizes energy transition to ensure effectiveness, inclusiveness

Lyudmyla Zahvoyska - Corresponding Member of the Forestry Academy of Sciences of Ukraine, PhD in Economic Sciences, Associate Professor of the Department for Ecological Economics. Ukrainian National Forestry University, 103 General Chuprynka st., Lviv, 79057, Ukraine. Tel.: +38-050-371-44-29. E-mail: lyudmyla. zahvoyska@nltu.edu.ua ORCID: https://orcid.org/0000-00020028-4723

Olha Bletska - Master of Environmental and Natural Resource Economics, Ukrainian National Forestry University, 103 General Chuprynka st., Lviv, 79057, Ukraine. Tel.: +38-068-532-70-37; E-mail: olyakhust@gmail.com ORCID: https://orcid.org/00000002-0467-8068 and environmental safety of energy generation processes. One of the pillars of the process is a transition to sustainable use of wood biomass in the residential sector using energy cooperatives as a mean for the transition process facilitation. This transition process deals with a nexus of changes induced in different realms like social, ecological, economic, technological, educational etc. Counterintuitive dynamics of the processes can create synergies or trade-offs.

To embrace a complexity of the process we proposed and applied system dynamics models. Causal loop diagram of the transition process was used to understand the scope. The model consists from two blocks: conceptual, which describes the general logic of the climate change mitigation, and operational one, which represents development of energy cooperatives (balancing and reinforcing loops correspondently).

Stock-flow diagram was proposed for quantitative analysis of the energy cooperatives development process. The model is based on the Bass model of innovation diffusion (1980) and Sterman model of its system dynamics (2000). The stock-flow diagram was parameterized according to realities of Boryslav city. Features of Ukrainian institutional landscape were examined using regression analysis of 11 indicators, aggregated in Global Competitiveness Index 4.0 (WEF, 2018) to reflect complexity of competitiveness. According to results of regression analysis, we complemented the stock-flow diagram with another parameter - Institutions - which describes dependence of individuals' economic activity on institutions' performance. Simulation run for 8-year period using the parameterized stock-flow model demonstrated quite weak transition toward energy cooperatives only $8.9 \%$ of homeowners - that can be explained by a poor performance of institutions in Ukraine.

However, according to a survey we conducted in Boryslav, $18.1 \%$ of the respondents are familiar with the concept of energy cooperatives, of which one in five was ready to invest in the cooperative development; about half of the respondents likely to change the heating systems in their homes, which is easier to manage through renewable energy cooperatives.

To get insight of wood biomass usage for Boryslav we run SWOT analysis and proposed four SWOT strategies for the process facilitation. These recommendations were tested against 'what-if' questions using the proposed causal loop diagram of the transition process to reveal potential unintended consequences, additional interventions and uncertainties resulted from the process complexity. These findings facilitate understanding and deliberative governance of the process.

Key words: transformation of energy systems; cooperative business model; SWOT analysis, SWOT strategies; regression analysis, closed-loop diagrams; stock and flow diagram; deliberative decision making. 